\title{
PENINGKATAN PENGETAHUAN OBAT DAN GIZI SELAMA KEHAMILAN MELALUI PROGRAM PENDAMPINGAN
}

\author{
1| Naniek Widyaningrum, 2| Wili Wahyu Timur, 3| Putri Novia Karmita Dewi, \\ 4| Serina Salmathifa Winarsih \\ Email Korespondensi : naniek.widyaningrum@gmail.com \\ Universitas Islam Sultan Agung, Indonesia
}

\begin{abstract}
Central Java is one of the contributors to our maternal and infant mortality rates in Indonesia. This increase was partly due to the knowledge of pregnant women about nutritional needs at the time of assessment. The purpose of this research is to increase the knowledge of pregnant women about the adequacy of nutrition and the use of drugs during pregnancy. The method used was assistance for pregnant women by professionals in their fields in September Obgyn Doctors and Pharmacists and descriptive analysis through questionnaires before and then conducted activities. Assistance activities carried out for one day in preparation for preliminary pregnant women in Pudak Payung. Based on the results of research people do not understand the importance of adequate nutrition during the assessment seen from a baby's low weight at his age. After mentoring, the increase in knowledge and awareness of pregnant women increased by $97 \%$.
\end{abstract}

\begin{abstract}
Abstrak
Jawa tengah merupakan salah satu penyumbang angka kamatian ibu hamil dan bayi di Indonesia. Peningkatan tersebut salah satunya karena faktor pengetahuan ibu hamil mengenai kebutuhan gizi pada saat kehamilan. Tujuan dilakukan penelitian adalah meningkatkan pengetahuan ibu hamil akan kecukupan gizi dan penggunaan obat selama kehamilan. Metode yang digunakan adalah pendampingan pada ibu hamil oleh tenaga professional dibidangnya seperti Dokter Obgyn dan Apoteker dan analisa deskriptif melalui kuisioner sebelum dan sesudah dilakukan kegiatan. Kegiatan pendampingan dilakukan selama satu hari sebagai gambaran pendahuluan kondisi ibu hamil di Pudak Payung. Berdasarkan hasil penelitian masyarakat belum mengetahui akan pentingnya kecukupan gizi selama kehamilan dilihat dari berat badan bayi yang rendah pada usianya. Setelah dilakukan pendampingan peningkatan pengetahuan dan kesadaran ibu hamil meningkat sebesar $97 \%$.
\end{abstract}

Kata Kunci: Pendampingan Ibu Hamil; Gizi; Pengunaan Obat

\section{PENDAHULUAN}

Jumlah angka kematian Ibu hamil di Indonesia mengalami peningkatan pada tahun 2014 yaitu mencapai 711 kasus, dari tahun sebelumnya mencapai 611 kasus. Kasus tersebut belum mencapai yang ditargetkan oleh MDGs (Millenium Development Goals) bahkan cenderung mengalami penurunan target(1). Seiring meningkatnya kasus kematian ibu hamil kasus kekurangan gizi ibu hamil di Jawa Tengah mengalami kenaikan pada tahun 2014 sebanyak 30\%. Kelurahan pudak payung, Semarang merupaka salah satu penyumbang angka kematian ibu hamil di Jawa Tengah(2).

Upaya pencegahan kematian ibu hamil dan bayi dapat dilakukan sedini mungkin dengan mengikuti pemeriksaan awal kehamilan untuk mengidentifikasi kemungkinan yang dapat terjadi selama masa kehamilan. Sebagian ibu hamil tidak 
melakukan kontrol kehamilannya dan tidak melakukan kontrol kesehatan(3). Tidak dilakukan kontrol kesehatan dapat mengakibatkan tidak diketahui apakah kehamilannya berjalan baik atau mengalami resiko tinggi yang dapat membahayakan kehidupan ibu dan bayi. Menurut Organisasi kesehatan dunia (WHO) program pemeriksaan bayi (antenatal care) merupakan upaya pencegahan untuk mengetahui keadaan yang tidak diinginkan selama kehamilan. Pemeriksaan awal selama kehamilan dapat mencegah dini resiko tinggi yang mungkin akan terjadi selama kehamilan sehingga dapat menurunkan angka kematian ibu hamil(4).

Pengetahuan merupakan determinan paling penting yang dapat mempengaruhi perilaku kesehatan bagi ibu hamil, pendampingan dapat meningkatkan pengetahuan dan perubahan perilaku selama kehamilan(5). Penelitian yang dilakukan oleh Ernawati(6), masalah gizi merupakan salah satu penyebab bayi lahir tidak sempurna bahkan mengalami kematian. Melahirkan bayi yang sehat tentu menjadi harapan semua ibu hamil. Untuk mendapatkan bayi sehat diperlukan perawatan serta menjaga kesehatan selama kehamilan. Upaya menjaga kesehatan dapat berupa mengonsumsi makanan yang bergizi, minum vitamin, memeriksa kehamilan secara teratur, istirahat yang cukup dan menjauhi segala hal yang dapat membahayakan ibu dan janin(7). Kebutuhan gizi pada masa kehamilan akan meningkat karena selain digunakan untuk ibu, juga untuk pertumbuhan janin itu sendiri. Calon ibu yang bijaksana tentu akan berusaha memenuhi kebutuhan gizi dengan baik sebagai upaya mendapatkan bayi dengan kondisi yang optimal akan beragam makanan secara proporsional dengan pola gizi seimbang dan 1 porsi lebih banyak daripada sebelum hamil. Istirahat yang cukup. Bagi ibu hamil kebutuhan energi yang dibutuhkan sebanyak 80.000 kalori pada 280 hari awal masa kehamilan (trimester I)(8).

Apabila ibu mengalami kekurangan gizi selama masa kehamilan dapat menyebabkan dampak buruk bagi ibu sendiri maupun janin. Terhadap ibu dampak yang timbul seperti pendarahan, anemia, terjadi infeksi, dan pertambahan berat badan yang tidak normal. Sedangkan dampak untuk janinnya seperti menghambat pertumbuhan janin, abortus, kematian neonatal, bayi lahir mati, anemia pada bayi, cacat bawaan, lahir dengan berat badan rendah (BBLR) hingga keguguran(7). Di Jawa tengah pendampingan pada saat kehamilan mulai dilakukan pada tahun 2011 oleh Dinas Kesehatan setempat, namun belum banyak ibu hamil yang rutin mengikutinya dikarenakan kurangnya kesadaran akan pentingnya pendampingan (Indri Astute, 2017). Untuk itu perlu dilakukan upaya pendekatan pada ibu hamil.

Berdasarkan uraian di atas maka perlu dilakukan peningkatan pengetahuan ibu hamil melalui pendampingan sebagai upaya menurunkan kejadian resiko kematian ibu hamil atau bayi dalam segi kecukupan gizi dan penggunaan obat yang dikonsumsi. 


\section{METODOLOGI PENELITIAN}

Pengambilan data dilakukan dengan metode survai deskriptif pada 20 ibu hamil di Kelurahan Pudak Payung, Banyumanik, Semarang. Metode penelitian deskriptif dapat digunakan untuk memecahkan atau menjawab permasalahan yang dihadapi pada saat ini(1). Penelitian ini dilakukan beberapa tahapan antara lain pemeriksaan diri ibu hamil, Konsultasi dan edukasi, pemutaran video seputar kesehatan ibu hamil serta melakukan penilaian terhadap pengetahuan ibu hamil Kelurahan Pudak Payung terhadap penggunaan obat dan gizi pada masa kehamilan. Penilaian dilakukan dengan menggunakan instrumen berupa kuisioner yang dibagikan sebelum dan sesudah dilakukan konsultasi dan pemberian materi edukasi. Kuisioner juga dilakukan untuk mengetahui derajat keberhasilan kegiatan pengabdian masyarakat di Kelurahan Pudak Payung, Banyumanik, Semarang.

Proses pendampingan dilakukan oleh tenaga medis yang profesional dalam bidangnya. Kegiatan pertama dilakukan pemeriksaan kesehatan dan Ultrasonografi (USG) dengan dokter obgyn untuk mengetahui kondisi ibu hamil dan pencegahan dini. Kegiatan dilanjutkan dengan konsultasi. Konsultasi merupakan program yang digunakan dalam berbagi pemahaman dan kepedulian antara narasumber dan ibu hamil. Konsultasi merupakan media untuk mengetahui masalah-masalah yang terjadi seputar kehamilan. Setelah dilakukan konsultasi maka ibu hamil diberikan edukasi sebagai solusi masalah baik masalah yang terjadi selama kehamilan atau sebagai upaya pencegahan. Pemutaran video dilakukan untuk memperjelas program edukasi yang telah diberikan dan untuk merangkum atau mengingat kembali edukasi yang telah diberikan. Materi yang diberikan seputar penggunaan obat dan kecukupan gizi selama hamil. Sebagai indikator keberhasilan pendampingan dan kegiatan pengabdian masyarakat dilakukan pembagian kuisioner yang berisikan sejumlah pertanyaan untuk ibu hamil, kuisioner dibagikan sebelum dan sesudah dilakukan pendampingan. Presentase hasil pretest dan post test digunakan sebagai derajat keberhasilan kegiatan dilakukan analisis secara deskriptif.

\section{HASIL DAN PEMBAHASAN}

Kegiatan pendampingan ibu hamil dalam upaya peningkatan pengetahuan obat dan gizi selama kehamilan di Kelurahan Pudak Payung Semarang, dengan total 20 Ibu Hamil. Pendampingan dilakukan pada kehamilan usia trisemester pertama. Sebelum dilakukan pendampingan dilakukan pengisian persetujuan Informed consent. Digunakan kuisioner sebagai indikator tingkat pengetahuan Ibu hamil. Kegiatan pretest dilakukan untuk mengukur tingkat pengetahuan Ibu hamil mengenai penggunaan obat dan gizi selama hamil sebelum dilakukan edukasi. 


\section{Tabel 1. Perbedaan pengetahuan sebelum dan sesudah dilakukan pendampingan terhadap Ibu hamil di Kelurahan Pudak Payung, Semarang}

\begin{tabular}{lll}
\hline Pengetahuan & Nilai Rata-Rata & \\
& $(\mathrm{n}=20)$ & Presentase kenaikan (\%) \\
Pretest & 45 & $93 \%$ \\
Postest & 87 & \\
\hline
\end{tabular}

Pemeriksaan kondisi ibu hamil dilakukan oleh tenaga profesional yaitu Dokter obgyn. Pemeriksaan selama kehamilan penting dilakukan. Pemeriksaan kandungan dilakukan minimal 4 kali selama kehamilan. Selain gizi, pemeriksaaan kandungan diketahui dapat menurunkan angka kematian ibu hamil dan digunakan sebagai pemantauan kondisi janin dan ibu hamil sebelum dilakukan persalinan(9). Ibu hamil di Kelurahan Pudak Payung, Semarang berkisar antara 20-30 tahun. Dalam pemeriksaan yang dilakukan 6 dari 20 korespondensi mendapatkan perhatian khusus dikarenakan hasil saat pemeriksaan menujukkan hasil yang kurang baik. Hasil dari pemeriksaan ultrasonografi terlihat berat badan bayi dalam kandungan tidak sesuai usia kandungan. Pada trisemester pertama berat badan bayi berkisar antara 0,500 - 2000 Gram. Kurangnya berat bayi pada trisemester pertama mempunyai pengaruh lebih besar terhadap berat lahir(10). Penyebab kurangnya berat badan bayi dapat dikarenakan karena ketidakcukupan konsumsi makanan pada ibu hamil. Ketidakcukupan makanan yang dikonsumsi akan berpengaruh pada gizi yang diperoleh oleh bayi dalam kandungan sehingga akan menyebabkan berat badan bayi rendah. Hasil penelitian yang telah dilakukan janin yang mnegalami kekurangan gizi selama kehamilan semester pertama akan mengalami penurunan regulasi pertumbuhan, berat lahir yang kurang dengan tubuh janin yang kecil. Usia janin pada trisemester pertama merupakan tahapan pembentukan organ, sehingga apabila gizi dan makanan yang dikonsumsi oleh ibu hamil megalami kekurangan maka akan berpengaru pada perkembangan organ(10).

Kegiatan pretest yang dilakukan didapatkan rata-rata pengetahuan Ibu hamil mengenai penggunaan obat dan kebutuhan gizi selama hamil sebesar $45 \%$. Presentase tersebut masih tergolong rendah. Tingkat pengetahuan wanita hamil mengenai gizi yang diperlukan selama kehamilan diketahui mempengaruhi keadaan bayi. Angka Kematian Bayi (AKB) di Indonesia masih tergolong tinggi yaitu 32 per 1000 kelahiran, target yang diharapkan sebesar 23 per 1000 kelahiran hidup(11). Angka kematian bayi yang terjadi salah satunya disebabkan karena kurangnya gizi yang diperlukan selama proses kehamilan. Gizi yang kurang akan mempengarui pertumbuhan, perkembangan dan tumbuh kembang bayi, bahkan hal tersebut tidak hanya berpengaruh selama di dalam kandungan namun hingga bayi lahir dan tumbuh 
dewasa(12). Angka gizi yang dibutuhkan selama masa kehamilan berbeda sebelum masa kahamilan. Berdasarkan Angka Kecukupan Gizi (AKG) 2013 diperlukan tambahan 330 kkal selama sehari pada saat masa kehamilan. Tambahan tersebut diantaranya protein $20 \mathrm{gr} /$ hari, lemak $10 \mathrm{~g}$ /hari dan karbohidrat 40g/hari(13).

Untuk meningkatkan pengetahuan kegiatan edukasi perlu dilakukan edukasi tentang pentingnya gizi untuk ibu hamil dan bayi yang tepat sesuai dengan takaran yang diperlukan selama kehamilan. Asupan konsumsi zat energi, protein, lemak dan karbohidrat yang kurang dapat mempengaruhi berat badan lahir bayi. Kebutuhan akan makronutrien selama kehamilan diperlukan dikarenakan meningkatnya kebutuhan gizi ibu selama masa kehamilan yang digunakan untuk memenuhi perubahan metabolik, fisiologi selama kehamilan dan juga digunakan untuk pertumbuhan janin dalam kandungan(7). Edukasi mengenai gizi yang sesuai digunakan oleh ibu hamil serta perawatan terhadap ibu hamil sangat penting dilakukan guna memperkecil resiko cacat pada janin, dan gangguan kesehatan yang tidak diinginkan. Karena konsumsi gizi yang tidak sesuai selama masa kehamilan dapat menyebabkan bayi lahir dengan berat badan rendah sampai retardasi mental atau gangguan fisik yang berat, karena bayi dengan gizi baik dalam sejak kandungan mempunyai kemungkinan mulai awal kehidupan dalam kondisi sehat fisik dan mental(14).

Selain mengenai gizi, Tidak semua obat aman digunakan selama kehamilan terutama pada trisemester pertama yang sangat rentan terhadap konsumsi obat karena dapat memperlambat hingga menghambat perkembangan bayi. Bayi dapat lahir dengan cacat dikarenakan penggunaan obat yang tidak seharusnya(15). Pentingnya pendampingan oleh Apoteker mengenai penggunaan obat sangat diperlukan terutama di Kota Semarang. Ibu hamil sangat disarankan untuk melakukan pemeriksaan kehamilan rutin selama kehamilan. Sebelum mengkonsumsi obat bebas diharapkan dapat melakukan konsultasi kepada Apoteker. Ibu hamil tidak disarankan untuk mengkonsumsi obat secara bebas tanpa pengawasan oleh tenaga medis. Sebesar 40\% korespondensi di Kelurahan Pudak Payung belum mengetahui pengunaan obat yang aman digunakan selama kehamilan. Studi menerangkan bahwa $44 \%$ wanita hamil menggunakan obat tanpa pengawasan tenaga medis. Penggunaan herbal pada saat kehamilan juga perlu dilakukan pengawasan, sebesar $77 \%$ wanita hamil mengkonsumsi herbal tanpa pengawasan dan dosis yang tidak sesuai(16). Sebesar 22\% wanita hamil tidak mengetahui keamanan penggunaan obat yang telah dikonsumsi(17).

\section{KESIMPULAN}


Berdasarkan hasil pretest yang dilakukan pengetahuan ibu hamil sebelum di lakukan pendampingan adalah 45\%. Kurangnya pengetahuan sebelum dilakukan pendampingan yaitu mengenai pentingnya melakukan pemeriksaan rutin selama kehamilan, dan kurangnya kesadaran ibu hamil untuk mengkonsumsi makanan yang bergizi. Ibu hamil cenderung mengkonsumi makanan sesuai keinginan tanpa mengetahui kecukupan gizinya. Setelah dilakukan pendampingan pengetahuan ibu hamil meningkat sebesar 97\% di Kelurahan Pudak Payung, Semarang.

\section{DAFTAR PUSTAKA}

1. Utami S. Studi Deskriptif Pendampingan Ibu Hamil Oleh Mahasiswa di Kabupaten Brebes Tahun 2013. 2018. p. 39-45.

2. Dinas kesehatan. Profil Kesehatan Kota Semarang 2015. Semarang; 2015.

3. Wuriningsih AY, Wahyuni S, Rahayu T, Distinarista H, Astuti IT, Khasanah NN, et al. Pendampingan Ibu Hamil Melalui Program One Student One Client (Osoc) Di Wilayah Kerja Puskesmas Genuk Semarang. Prosiding Seminar Nasional \& Internasional. 2017;1(1):720-9.

4. Ramli N. DI KABUPATEN ACEH BESAR ( The influence of community assistance to the implementation of midwifery care to pregnant women in Aceh Besar District ). Jurnal AcTion: Aceh Nutrition Journal. 2017;2(November):137-48.

5. Setyaningsih Reni, Adriyani Prasanti UM. Kehamilan Di Kabupaten Banyumas. Jurnal Pengabdian Kepada Masyarakat. 2016;22(3):135-9.

6. Ernawati A. Masalah gizi pada ibu hamil nutritional issues among pregnant mothers. Jurnal litbang. 2017;XIII(1):60-9.

7. Retni R, Margawati A, Widjanarko B. Pengaruh status gizi \& asupan gizi ibu terhadap berat bayi lahir rendah pada kehamilan usia remaja. Jurnal Gizi Indonesia. 2017;5(1):14.

8. Azizah A, Adriani M. Tingkat Kecukupan Energi Protein Pada Ibu Hamil Trimester Pertama Dan Kejadian Kekurangan Energi Kronis. Media Gizi Indonesia. 2018;12(1):21.

9. Maritalia D. Hubungan Pengetahuan Ibu Hamil tentang Periksaan Kehamilan terhadap Kunjungan ANTE NATAL CARE (ANC) di Puskesmas Makmur Kabupaten Bireuen. Lentera. 2015;15(13).

10. Sari M, Sudiarti T. Model Prediksi Berat Lahir Bayi Berdasarkan Berat Badan Ibu Hamil. Kesmas: National Public Health Journal. 2013;7(8):339.

11. Syari M, Serudji J, Mariati U. Peran Asupan Zat Gizi Makronutrien Ibu Hamil terhadap Berat Badan Lahir Bayi di Kota Padang. Jurnal Kesehatan Andalas. 2015;4(3):729-37. 
12. Saragih ID. Gambaran Berat Lahir Rendah Berdasarkan Kualitas Pelayanan Antenatal Care di Indonesia Tahun 2012. Jurnal Jumantik. 2017;2(2):60-77.

13. Almatsier S. Prinsip Dasar Ilmu Gizi. Gramedi Pustaka Utama; 2011. 54-65 p.

14. Abdushshofi MF, Elvina R, Hersunaryati Y. Evaluasi Ketepatan Penggunaan Obat Ibu Hamil di Departemen Obstetri dan Gunekologi Rumah Sakit 'X'. Farmasains : Jurnal Ilmiah Ilmu-Ilmu Kefarmasian. 2016;3(1):21-9.

15. Wulandari C, Setiyarini DW, Bariroh K, Laraswati L, Azhari MF, Ibnu Aziz RA. Upaya Peningkatan Status Kesehatan Kelompok Rentan dengan Pendekatan Pembelajaran dan Pemberdayaan Masyarakat. Jurnal Pengabdian kepada Masyarakat (Indonesian Journal of Community Engagement). 2019;5(2):167.

16. Pranasti EA, Abdulah R. Drug UTILIZATION RESEARCH Pada Wanita Hamil, Pediatri dan Geriatri. Farmaka. 2018;15(1):115-22.

17. Sattari M, Dilmaghanizadeh M, Hamishehkar H, Mashayekhi SO. Self-reported use and attitudes regarding herbal medicine safety during pregnancy in Iran. Jundishapur Journal of Natural Pharmaceutical Products. 2012;7(2):45-9. 